\title{
A complex of factors of increasing the competitiveness of industrial park residents
}

\author{
E.A. Tikhanov ${ }^{1}, V . V$. Krivorotov ${ }^{1}, P . V$. Chepur $^{2}, A . A$. Tarasenko $^{2}$, and $A . A$. \\ Gruchenkova ${ }^{3, *}$ \\ ${ }^{1}$ Ural Federal University named after the first President of Russia B. N. Yeltsin, 620002 Mira Street \\ 19, Russia \\ ${ }^{2}$ Industrial University of Tyumen, 625000 Volodarskogo Street 38, Russia \\ ${ }^{3}$ Surgut Oil and Gas Institute, 628405 Entuziastov Street 38, Russia
}

\begin{abstract}
In the paper, industrial parks are considered as the most dynamically developing, universal and effective format of the investment infrastructure organization. A whole range of advantages for enterprises resident in industrial parks when placing production in such investment sites actualizes the need to study industrial parks as an effective mechanism to increase the competitiveness of Russian industrial enterprises and to identify a set of factors that contribute to the growth of competitiveness of industries located within the boundaries of industrial parks. Based on the analysis of the aggregate of advantages of industrial park residents, the authors proposed a system of factors of increasing their competitiveness, which includes three aggregated blocks: "intra-park" factors, local factors and regional factors. A considerable influence of each block of factors on key performance indicators and the competitive position of the resident enterprises of industrial parks has been discovered. The basis for the development of a system of indices for the functioning of industrial parks has been created, which makes it possible to quantify the impact of factors proposed by the authors of the system.
\end{abstract}

\section{Introduction}

Foreign and domestic experience demonstrates the relevance of the formation of a prepared investment infrastructure for the business, which is the basis for the development of the industry, increasing its competitiveness, and also allowing enterprises to create modern production at minimal costs and in optimal terms.

To date, the most dynamically developing, universal and effective format of organizing investment sites are industrial parks, which are infrastructurally and organizationally prepared areas for the deployment of new industrial production [1-4]. The variety of industrial park types has made them a flexible tool to meet a wide range of specific targets (Table 1).

The key distinguishing features of industrial parks in comparison with other forms of investment infrastructure organization are $[5,6]$ :

\footnotetext{
*Corresponding author: alesya2010-11@yandex.ru
} 
- the possibility for a wide range of public and private actors to act as initiators of such projects;

- the possibility of forming sites of various scale - from small (several hectares) to gigantic (several thousand hectares) - taking into account the territorial features and business needs;

- the possibility of placing an industrial park of enterprises of any size on the site - both small and medium-sized enterprises, and large Russian and foreign companies;

- the possibility of implementing an unlimited number of projects to create industrial parks within the borders of the region, which allows companies to choose the optimal place to locate their production;

- the possibility of forming a set of unique tax, financial and administrative preferences granted to enterprises operating within the territory of industrial parks at the regional level.

Table 1. Groups of industrial parks.

\begin{tabular}{|c|c|c|}
\hline Classification & $\begin{array}{l}\text { Industrial park } \\
\text { type }\end{array}$ & Brief description \\
\hline \multirow{3}{*}{$\begin{array}{l}\text { Forms of } \\
\text { ownership }\end{array}$} & State & $\begin{array}{l}\text { Land owned by the state or a management company } \\
\text { specially created for managing the park. The management } \\
\text { company is created by the executive government bodies. }\end{array}$ \\
\hline & Private & $\begin{array}{l}\text { The owner or long-term lessee of the land is a private } \\
\text { management company established by a private investor. }\end{array}$ \\
\hline & $\begin{array}{l}\text { Public and private } \\
\text { partnership }\end{array}$ & $\begin{array}{l}\text { Attraction of a private investor to the industrial park } \\
\text { project by creating a joint management company. The } \\
\text { ownership of the land can be transferred to the } \\
\text { management company as an equity payment. }\end{array}$ \\
\hline \multirow{3}{*}{$\begin{array}{l}\text { The type of } \\
\text { site }\end{array}$} & Greenfield & $\begin{array}{l}\text { The land for the park is undeveloped, so the necessary } \\
\text { engineering infrastructure needs to be built. }\end{array}$ \\
\hline & Brownfiled & $\begin{array}{l}\text { The park is located in a built-up area and uses the existing } \\
\text { infrastructure and/or buildings. }\end{array}$ \\
\hline & Mixed type & $\begin{array}{l}\text { In practice there are projects the first stages of which are } \\
\text { realized on the alreadydeveloped area (Brownfield) with } \\
\text { further extension into the undeveloped area (Greenfield). }\end{array}$ \\
\hline \multirow{2}{*}{$\begin{array}{l}\text { Specialization } \\
\text { of the } \\
\text { industrial } \\
\text { park }\end{array}$} & Specialized & $\begin{array}{l}\text { Attraction of resident companies from one branch of } \\
\text { industry. }\end{array}$ \\
\hline & All-purpose & $\begin{array}{l}\text { No strict boundaries to industry classification of } \\
\text { enterprises. }\end{array}$ \\
\hline \multirow{3}{*}{$\begin{array}{l}\text { Allocation of } \\
\text { residents }\end{array}$} & $\begin{array}{l}\text { Sale and lease of } \\
\text { land for building } \\
\text { enterprises }\end{array}$ & $\begin{array}{l}\text { Granting residents land for development. } \\
\text { Most attractive for medium-sized and large enterprises. }\end{array}$ \\
\hline & $\begin{array}{l}\text { Lease of finished } \\
\text { buildings/workshops }\end{array}$ & $\begin{array}{l}\text { Construction of manufacturing facilities to let them out on } \\
\text { lease to residents. Particularly attractive for small and } \\
\text { medium-sized companies. } \\
\text { Increases the amount of the required initial investment. }\end{array}$ \\
\hline & Mixed & $\begin{array}{l}\text { Availability of sites for sale and lease as well as finished } \\
\text { buildings and workshops for residents. }\end{array}$ \\
\hline
\end{tabular}

Considering the indicated features, industrial parks today become points of economic growth of territories and attraction of direct investments in the regions. The main competitive advantages of such sites for resident enterprises include the possibility of reducing the time and financial costs for the organization of production, an advantageous location in relation to transport routes, raw materials and finished goods markets, and targeted support for residents of industrial parks by the state [7-9].

A whole range of advantages in the location of production facilities on the territory of the industrial park actualizes the need for its study as a platform for creating an effective 
mechanism to enhance the competitiveness of Russian industrial enterprises and to identify a set of factors that contribute to the competitiveness of production sites located within the boundaries of similar sites [10-14].

\section{Methods}

In order to systematize the entire set of advantages of resident enterprises of industrial parks, the authors suggest dividing factors of increasing their competitiveness into three enlarged blocks (Figure 1):

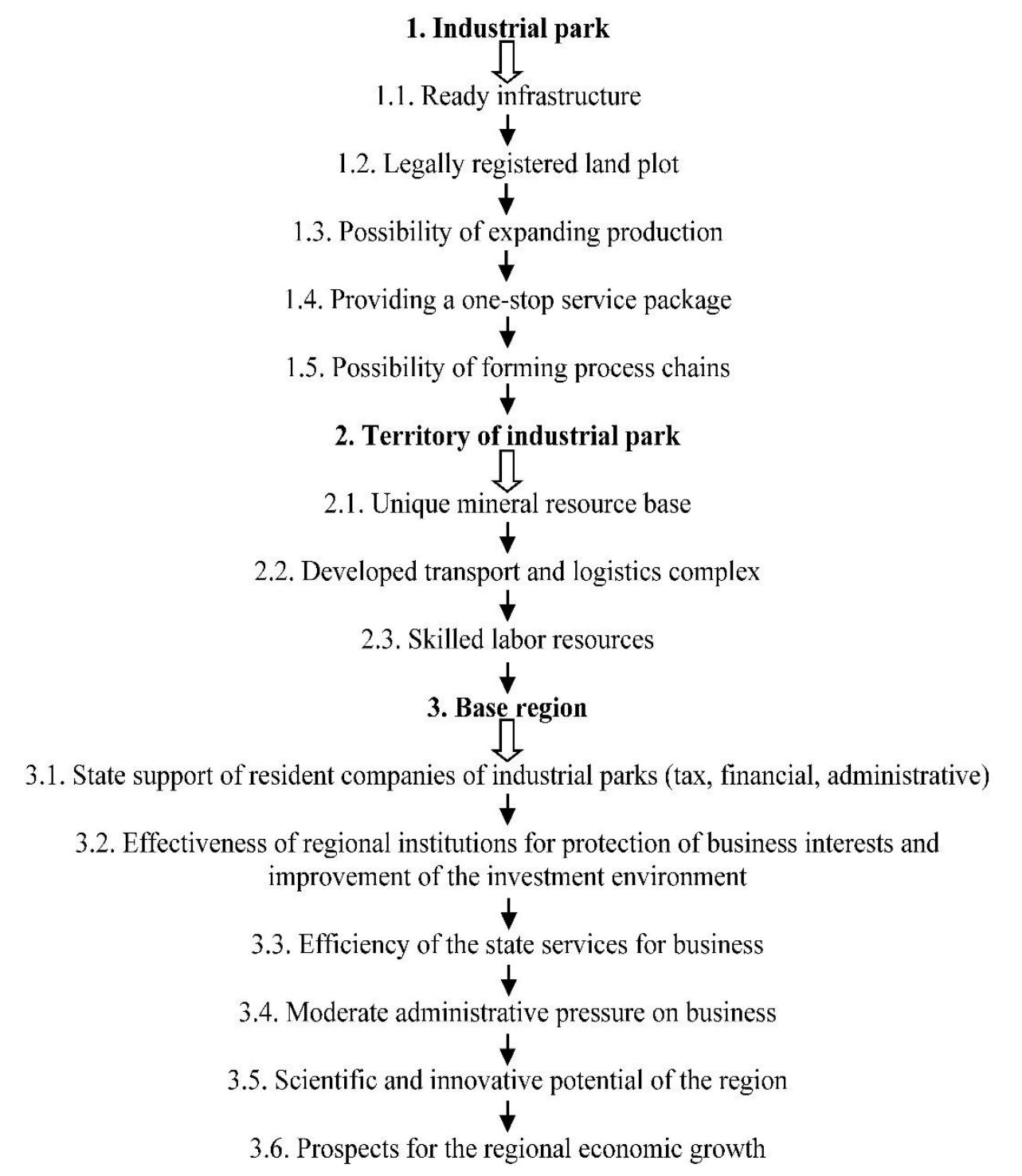

Fig. 1. System of factors of increasing the competitiveness of enterprises operating on the territory of an industrial park. 
- "intra-park" factors that characterize a complex of conditions formed within the boundaries of the industrial park to create new industries, as well as opportunities for their further development;

- local factors that characterize the geographical, personnel, and resource advantages of the territory located in the immediate vicinity of the industrial park;

— regional factors characterizing the advantages given to resident companies of industrial parks when locating production within the territory of a certain subject of the Russian Federation.

The block of "intra-park" factors will include:

— ready engineering and transport infrastructure facilities, industrial buildings and facilities within the industrial park;

- a legally registered land plot and administrative and legal conditions necessary for the organization of production;

- a property management company of the industrial park, providing the resident companies with a one-stop service package;

- possibility of expanding production within the boundaries of the industrial park;

— possibility of forming process chains of interaction with the resident enterprises of the industrial park.

The block of local factors includes:

- a unique natural and/or technogenic mineral resource base near the territory of the industrial park;

— skilled labor resources necessary for the organization of production in the industrial park;

- a developed transport and logistics complex in the area of the industrial park location.

The block of regional factors includes the following:

- a set of state support measures provided by the regional authorities for the resident companies of industrial parks;

— effectiveness of regional institutions for protection of business interests and improvement of the investment environment;

— efficiency of the state services for business during obligatory registration and licensing procedures;

- moderate administrative pressure on business;

— scientific and innovative potential of the region;

- prospects for the regional economic growth.

\section{Results and discussion}

The group of "intra-park" factors has the most significant impact on the competitiveness of industrial park residents. So, the lack of the need to solve the problems of infrastructure support of the production being created and coordination with the specialized services of fire and environmental safety issues allows investors to start implementing projects with minimal time and financial costs, shortening their payback periods, and in case of locating enterprises on the territory of state industrial parks - save costs for connection to infrastructure facilities, purchase or lease of industrial buildings and facilities.

Using the services provided by the property management company, the residents of the industrial park have the opportunity not to divert their own resources to solve non-core tasks: transfer non-production functions to the management company for outsourcing, optimize overhead costs by providing the management company with the optimal market value of the services provided, reduce the amount of capital investments in the construction of its own infrastructure facilities through the use of centralized infrastructure, avoid losses at the initial 
stages of production development, attracting specialists of the management company having experience in various industries.

At the same time, integration within the industrial park of suppliers and consumers within the framework of a single technological process makes it possible to increase the level of production effectiveness and quality of manufactured products based on the experience of partner enterprises and advanced industry standards, save on logistics costs, reduce costs by concentrating resources on one or several technological processes, have stable supply of raw materials and demand for finished products.

Local factors also largely form a competitive position of enterprises operating within the boundaries of industrial parks. The location of industrial parks in close proximity to large cities, especially regional centers, characterized by a high concentration of higher education institutions, research institutes, high-tech industrial enterprises, as well as the development of a scientific and technical base, allows residents to reduce the risks of labor shortage and minimize costs on the selection of specialists with the required level of qualification.

The proximity of raw materials guarantees residents stability of supplies and a reduction in transportation costs, and also allows the use and development of highly specialized, competitive technologies based on local raw materials.

A significant advantage of the industrial park, making the markets for finished products more accessible to residents, is the transport accessibility of the site. The proximity of the industrial park to major highways and railways of federal and regional importance, international airports, river and sea ports contributes to the diversification of the directions of supply of raw materials and the expansion of the geography of sales of products produced by resident enterprises. This allows companies to optimize the material costs for the acquisition of raw materials and the sale of finished products, and to plan an increase in production capacity taking into account the prospects of new markets.

Considering that for regional authorities industrial parks are becoming centers of economic growth of the territory and one of the main instruments for attracting investments in the real sector of the economy, residents of industrial parks are identified as a separate category of investors and receive a whole range of preferences at the level of regional legislation. State support of resident companies of industrial parks contributes to the growth of economic efficiency of investment projects implemented within the territory of industrial parks by reducing the tax burden on companies and providing the possibility of attracting budgetary financing, reducing administrative risks for investors associated with the actions of public authorities that may lead to negative changes in the operating conditions of the enterprise. Also, the impact of the factors of this group is expressed in the increase in the dynamics of business development and stability of resident enterprises of industrial parks.

The system of factors of increasing the competitiveness of residents of industrial parks clearly demonstrates the complex of advantages received by enterprises that locate production on the territory of such investment sites.

At the same time, the proposed system of factors is the basis for the development of a system of indicators for the functioning of an industrial park, which makes it possible to obtain a quantitative assessment of their impact, necessary to carry out a study of the influence of these factors on the level of competitiveness of enterprises that are residents of industrial parks [15-17].

\section{Conclusions}

In the course of the work, key features of industrial parks were identified, which make it possible to consider them as the most universal and effective format for the organization of investment sites. The complex of advantages received by the enterprises as a result of creation of production within the territory of industrial parks is analyzed. 
The system of factors of increasing the competitiveness of resident enterprises of industrial parks is developed, which includes three groups of indicators: a block of "intrapark" factors, a block of local factors and a block of regional factors. The positive influence of the proposed system of factors on the performance indicators and the competitive position of enterprises operating within the boundaries of industrial parks is analyzed.

The basis for the development of a system of indicators for the functioning of industrial parks has been formed, which makes it possible to evaluate and analyze the impact of factors of increasing competitiveness on the activities of residents of industrial parks.

\section{References}

1. R.E. Mansurov, Market. in Rus. and abroad 2(25), 91-94 (2006)

2. E.I. Mazilkina, G.G. Panichkina, Upravlenie konkurentosposobnost'yu (Omega-L, Moscow, 2007)

3. E.M. Korotkov, Menedzhment (INFRA-M, Moscow, 2010)

4. O.V. Savinova, M.A. Istrashkina, Econ. of educ. 5, 135-152 (2012)

5. V.V. Krivirotov, A.V. Kalina, E.A. Tikhanov, S.E. Erypalov, Vestnik of the Ural Fed. Univ. 2, 61-74 (2014)

6. V.L. Belousov, Analiz konkurentosposobnosti firmy (Marketing in Russia and abroad, Moscow, 2007)

7. K.G. Borodin, Konkurentosposobnost'v rynochnoy ekonomike (Teis, Moscow, 2006)

8. V.A. Bykov, T.G. Filosofa, Konkurentsiya. Innovatsii. Konkurentosposobnost' (Uniti, Moscow, 2008)

9. V.V. Krivirotov, Metodologiya formirovaniya mekhanizma upravleniya konkurentosposobnost'yu predpriyatiya (Ural State Technical University, Yekaterinburg, 2007)

10. V.V. Krivirotov, I.V. Ershova, I.S. Belik, Konkurentosposobnost' sotsial'noekonomicheskikh sistem: vyzovy novogo vremeni (Economika, Moscow, 2014)

11. A.L. Denisova, N.V. Ylyakhin, Upravlenie konkurentosposobnost'yu promyshlennogo predpriyatiya: aspekty kachestva (Tambov state technical University, Tambov, 2006)

12. T.Yu. Ivanova, V.I. Prikhodko, Teoriya organizatsii (KnoRus, Moscow, 2010)

13. A.Yu. Yudanov, Konkurentsiya: teoriya i praktika (Gnom-Press, Moscow, 2009)

14. A. Shulus, Investm. in Rus. 12, 11-19 (2012)

15. V.P. Zotov, Kompleksnyy ekonomicheskiy analiz khozyaystvennoy deyatel'nosti (Kemerovo, 2009)

16. V.V. Krivirotov, A.V. Kalina, T.V Matveeva, A.Yu. Bayranshin, Povyshenie konkurentosposobnosti sovremennykh rossiyskikh territorial'no-proizvodstvennykh kompleksov (Ural State Technical University, Yekaterinburg, 2013)

17. V.V. Krivirotov, A.V. Kalina, V.D. Tretyakov, E.A. Tikhanov, K.E. Parfenov, Vestnik of the Ural Fed. Univ. 4, 61-76 (2013) 